\title{
Adherence to diabetes mellitus care at three levels of health care
}

\author{
Adesão ao cuidado em diabetes mellitus nos três níveis de atenção à saúde
} La adhesión a la atención en la diabetes mellitus en tres niveles de atención de la salud

\author{
Jackline Duran Souza ${ }^{1}$ \\ Marcelo Henrique Barbosa Baptista ${ }^{1}$ \\ Danielle dos Santos Gomides ${ }^{1}$ \\ Ana Emilia Pace
}

1. Escola de Enfermagem de Ribeirão Preto, Universidade de São Paulo. Ribeirão Preto, São Paulo, Brazil
Corresponding author: Ana Emilia Pace.

E-mail: aepace@eerp.usp.br

Submitted on 03/07/2017. Accepted on 08/06/2017.

DOI: 10.1590/2177-9465-EAN-2017-0045

\begin{abstract}
Objective: To evaluate adherence to self-care among people with diabetes mellitus cared for at the three levels of health care. Method: Quantitative, descriptive, cross-sectional study addressing a sample of 143 people from a city in the interior of São Paulo, Brazil from primary (45), secondary (48) and tertiary (50) units. Adherence to self-care was assessed using the "The Summary of Diabetes Self-Care Activities Measure" and "Measurement of Treatment Adherence". Results: Adherence to exercises, blood glucose monitoring, shoe inspection, and the use of insulin differed between units; better results were obtained for those in tertiary care. Conclusion: The results indicate a need for greater investment in the initial phase of treatment to improve self-care adherence. Implications for practice: The study enabled identifying the profile of individuals in terms of self-care adherence and supporting the planning of nursing interventions in diabetes mellitus.
\end{abstract}

Keywords: Medication adherence; Self-care; Diabetes Mellitus; Nursing Care.

\section{Resumo}

Objetivo: Avaliar a adesão ao cuidado à doença em pessoas com diabetes mellitus, atendidas nos três níveis de atenção à saúde. Método: Estudo quantitativo, descritivo, transversal, em amostra de 143 pessoas de um município do interior paulista provenientes das unidades de atenção primária (45), secundária (48) e terciária (50). A adesão ao cuidado foi avaliada por meio do "Questionário de Atividades de Autocuidado com o Diabetes" e o "Teste de Medida da Adesão ao Tratamento". Resultados: A adesão para a atividade física, monitorização da glicemia capilar, inspeção dos calçados e uso de insulina diferiu entre as unidades com melhores resultados na atenção terciária. Conclusão: Os resultados indicam a necessidade de maiores investimentos na fase inicial do tratamento para melhorar a adesão. Implicações para a prática: $O$ estudo possibilitou identificar o perfil da adesão ao cuidado à doença e subsidiar o planejamento das intervenções de enfermagem, na atenção em diabetes mellitus.

Palavras-chave: Adesão à Medicação; Autocuidado; Diabetes Mellitus; Cuidados de Enfermagem.

\section{RESUMEN}

Objetivo: Evaluar la adherencia al cuidado de personas con diabetes mellitus asistidas en tres niveles de atención a la salud Método: Estudio cuantitativo, descriptivo, transversal, muestra de 143 personas de un municipio de São Paulo, provenientes de unidad atención primaria (45), secundaria (48) y terciaria (50). Se evaluó la adherencia utilizando el "Cuestionario de Actividades de Autocuidado con la Diabetes" y la "Prueba de Medición de Adherencia al Tratamiento". Resultados: La adherencia a la actividad física, monitoreo de la glucosa capilar, inspección del calzado y uso de insulina difirieron entre las unidades; mejores resultados en la atención terciaria. Conclusión: Se necesita una mayor inversión en el tratamiento precoz para mejorar la adherencia a los cuidados personales. Implicaciones para la práctica: Fue posible identificar el perfil de la adhesión al cuidado a la enfermedad, y subsidiar la planificación de las intervenciones de enfermería en la atención en diabetes mellitus.

Palabras clave: Adherencia a la Medicación; Autocuidado; Diabetes Mellitus; Cuidados de Enfermería. 


\section{INTRODUCTION}

Non-communicable diseases, such as heart diseases, cancer, diabetes, respiratory diseases and neuropsychiatric illnesses are a major health problem in Brazil and account for a high number of deaths before the age of 70 years old and a loss of quality of life. ${ }^{1}$

Diabetes Mellitus (DM) is highlighted in this study due to its growing prevalence rates in the country, estimated at 14.3 million people, and high mortality, with 130,700 deaths, i.e., more than half the number of deaths caused by DM in Central and South America. ${ }^{2}$

Once the disease is established, the prevention of complications is based on glycemic control, through a treatment that includes healthy eating, exercises, blood glucose monitoring, maintaining the integrity of skin on the feet and function, medication, and quitting smoking. ${ }^{3,4}$ In this context, we highlight that treatment adherence is essential to preventing complications.

In the international literature, discussion of adherence is denominated by compliance or adherence, but these denominations present different concepts. Compliance means one merely complies with medical recommendations, while adherence refers to the active, voluntary and collaborative participation of an individual in implementing the behaviors necessary to reach therapeutic results, participation in the establishment of goals, and treatment plannning. ${ }^{5}$

The term adherence, adesão in Portuguese, was adopted in this study. It is believed, within this concept, that demographic, social and psychological factors related to healthcare workers, to the health system and the disease, may interfere with it. ${ }^{5}$

Among these factors, the aging process and the clinical progression of DM may increase the susceptibility or accelerate comorbidities, which in turn, increases the therapeutic regimen's complexity and favors low adherence. ${ }^{6}$ An individual with DM may adhere to one self-care activity but not to others. ${ }^{5}$

The Brazilian literature reports a tendency of improved rates of medication adherence, regardless of the level of health care, $, 6,7,8,10$, but worse adherence rates concerning self-care activities like exercises, ${ }^{8}$ foot care ${ }^{7}$, and a healthy diet. ${ }^{7,8,10}$

In summary, the rates of medication adherence reported by studies are sometimes higher and sometimes similar among studies, regardless of the level of care at which individuals are monitored. Adherence to diet and exercise, however, is low, even though these are the behaviors indicated as the primary measures to control DM. $6,7,8,11$

Due to the importance of actions to support or strengthen treatment adherence at the time of diagnosis in order to prevent or delay associated morbidities, and also over the course of treatment to control such comorbidities, the assumption is that the profile of treatment adherence for individuals with DM in the different phases of the disease may be investigated at the different levels of health care, considering that the clinical characteristics that guide the care provided at each level represent the progression of the disease.
In order to verify whether treatment adherence changes according to the clinical progression of the disease, this study's objective was to identify treatment adherence among people with DM2 receiving outpatient care at the three levels of care.

\section{METHOD}

Descriptive, cross-sectional study with quantitative approach developed in outpatient units from a city in the interior of São Paulo, Brazil, corresponding to the three levels of care of the Brazilian Health System (SUS), that is, Primary Health Care (PHC) Unit, Secondary Health Care (SHC) Unit, and Tertiary Health Care (THC) unit.

Inclusion criteria included people diagnosed with DM2 at least one year prior, of either sex, aged at least 30 years old, and in outpatient follow-up. Those attending primary and secondary care units were selected through consultation of their medical files at the time of the pre-consultation, when they were invited to participate in the study and received clarification regarding the study's objectives. Free and informed consent forms were read out loud, two copies of which were then signed by those who consented.

Data from the participants of a tertiary unit were collected from the database of a previous descriptive study, the objective of which was to characterize self-care activities in a sample composed of 218 adults with DM, undergoing outpatient follow-up in a tertiary care unit. ${ }^{8} \mathrm{~A}$ total of 50 individuals were drawn from this database using the Statistical Package for the Social Sciences, stratified according to sex and age, in a way the final sample would represent the whole database, composing this study's sample.

The variables included in this study were: sociodemographic and clinical variables (duration of diagnosis, body mass index), laboratorial exams (glycated hemoglobin - HbA1c) and treatment adherence (self-care activities and medication adherence). The parameters established by the Brazilian Diabetes Society ${ }^{4}$ were considered when assessing the laboratorial exams, which considers $\mathrm{HbA} 1 \mathrm{c}>7 \%$ to be altered.

Self-care activities were assessed using the translated version adapted for Brazil ${ }^{3}$ of "The Summary of Diabetes Self-care Activities Measure (SDSCA)". ${ }^{12}$ This questionnaire addresses six domains: general diet, specific diet, physical activity, blood glucose monitoring, foot care, and medication, in addition to three items assessing smoking. The questions ask which care activities were performed by people with DM in the respective domains in the last seven days, that is, the answers range from zero to seven days/week. There are two items in the Specific Diet domain (2.2 and 2.3) with inverted scores $(0=7,1=6,2=$ $5,3=4,4=3,5=2,6=1$ and $7=0){ }^{3}$

The General Diet, Physical Activity, and Blood Glucose Monitoring domains present good correlations among items and can be assessed using a total mean score. The remaining domains should be assessed separately according to their individual items due to the weak correlation among them. ${ }^{3}$ 
The Brazilian version of the "Measurement of Treatment Adherence (MTA)"13, which was based on the Morisky Test ${ }^{14}$ and allows adherence to oral anti-diabetic drugs and insulin to be assessed separately, ${ }^{15}$ was applied.

The MTA contains a Likert scale composed of seven questions, each with six answer options, ranging from "one" = always to "six" = never. The total score is an average of the scores obtained for all questions; the higher the score, the greater the adherence. ${ }^{14}$

An instrument specifically developed to collect sociodemographic and clinical data was used. Laboratorial data were collected from the participants' medical files and the results of exams performed the closest to the date of the interview, within three months before or after the interview, were used. Data were collected from December 2013 to June 2014.

Data were double entered into an Excel spread sheet and processed in the Statistical Package for the Social Science (version 21.0). Numerical variables were presented using central tendency (mean and median) and variability measures (standard deviation - SD, and minimum and maximum values).

To verify whether there were differences in the results concerning self-care and medication adherence between the three levels of health care, the Kruskal-Wallis test was used and a significance level of $5 \%$ was established.

The study was approved by the Institutional Review Board at the University of São Paulo at Ribeirão Preto, College of Nursing (report No. 469.583/2013).

\section{RESULTS}

A total of 123 people were invited from among those cared for in the primary and secondary health units. Twenty-three out of the 123 refused to participate because they did not perceive any benefits from the study, did not have time, were physically indisposed, or had already participated in other studies addressing DM. Four did not attend the interview on the scheduled date even after having consented, and three were not included because their diagnosis had been established less than a year ago.

Therefore, the number of participants in these units was 93, which added to the 50 individuals from the tertiary unit, totaled
143 people: 45 individuals were from the $\mathrm{PHC}$ unit, 48 from the $\mathrm{SHC}$ unit, and 50 were from the THC unit (Figure 1).

The following stand out in the sample's sociodemographic characterization: mean age of approximately 60 years old and higher frequencies among females, and for the category "married/ stable relationship" at all three levels of care. Low education was also a common characteristic among the health units, the means of which decreased from PHC unit to THC and SHT units (Table 1).

Among the clinical variables, average time since diagnosis increased from the $\mathrm{PHC}$ unit to the $\mathrm{SHC}$ and THU units and insulin use also increased from $\mathrm{PHC}$ unit to the $\mathrm{SHC}$ and $\mathrm{THC}$ units, while the use of oral antidiabetic agents was reported by approximately $40 \%$ of the participants in the three different health units (Table 1 ).

The mean body mass index (BMI) of the participants in the three units indicated obesity, while the results concerning $\mathrm{HbA1c}$ were close to normal parameters among the participants from the $\mathrm{PHC}$ and $\mathrm{SHC}$ units, though those in the THC unit presented altered $\mathrm{HbA} 1 \mathrm{c}$. Note that it was not possible to obtain information regarding this last variable from all those receiving care in the PHC $(n=17)$ and SHC units $(n=29)$ because this information was not available in the medical files (Table 1).

The three groups obtained similar means in the General Diet domain $(p>0.05)$. The Physical Activity domain presented differences in the three levels of care, though all the units presented a low mean for days in all activities $(p<0.05)$. A difference was observed between groups in terms of Blood Glucose Monitoring $(p<0.05)$; the THC unit presented the highest score, followed by the SHC and PHC units (Table 2).

The units presented no differences $(p>0.05)$ concerning the items addressed in the Specific Diet and Medication domains. The lowest means were obtained in the item concerning the ingestion of fat-laden foods contained in the Specific Diet domain; the worst score was obtained by the SHC unit, followed by the $\mathrm{PHC}$ and THC units. Better results were obtained by all three levels of care in the Medication domain, though the item insulin use stood out: the $\mathrm{SCH}$ unit presented a minimum of zero days/ week, which was not observed in the PHC and the THC; and for the oral antidiabetic agents item; the three units presented a minimum of zero days/week (Table 3).

Figure 1. Samples from the three health units.

\begin{tabular}{|c|c|c|}
\hline $\begin{array}{c}\text { PHC unit } \\
67 \text { individuals were invited }\end{array}$ & $\begin{array}{c}\text { SHC unit } \\
56 \text { individuals were invited }\end{array}$ & $\begin{array}{c}\text { THC unit } \\
\text { Drawn from a previously } \\
\text { existing database }\end{array}$ \\
\hline 15 refusals & 8 refusals & \\
\hline 4 missed the interview & & \\
\hline 3 people with DM $2<1$ year & & \\
\hline 45 participants & 48 participants & 50 participants \\
\hline
\end{tabular}


Table 1. Sociodemographic and clinical data of the study sample, Ribeirão Preto, SP, Brazil 2017.

\begin{tabular}{|c|c|c|c|c|c|c|}
\hline \multirow[b]{2}{*}{ Variables } & \multicolumn{3}{|c|}{ Mean (SD*) or Number (\%) } & \multicolumn{3}{|c|}{ Median (interval) } \\
\hline & $\begin{array}{c}\text { PHC } \\
n=45^{\text {a }}\end{array}$ & $\begin{array}{c}\text { SHC } \\
n=48^{b}\end{array}$ & $\begin{array}{c}\text { THC } \\
n=50^{c}\end{array}$ & PHC & SHC & SHC \\
\hline \multicolumn{7}{|l|}{ Sex } \\
\hline Male & $\begin{array}{c}10 \\
(22.2)\end{array}$ & $\begin{array}{c}20 \\
(41.7)\end{array}$ & $\begin{array}{c}27 \\
(54.0)\end{array}$ & & & \\
\hline Female & $\begin{array}{c}35 \\
(77.8)\end{array}$ & $\begin{array}{c}28 \\
(58.3) \\
\end{array}$ & $\begin{array}{c}23 \\
(46.0)\end{array}$ & & & \\
\hline Age (complete years) & $\begin{array}{c}66.5 \\
(12.5)\end{array}$ & $\begin{array}{l}62.5 \\
(9.5)\end{array}$ & $\begin{array}{l}60.80 \\
(8.6)\end{array}$ & $\begin{array}{c}67 \\
(35-91)\end{array}$ & $\begin{array}{c}62.5 \\
(36-79)\end{array}$ & $\begin{array}{c}60 \\
(41-78)\end{array}$ \\
\hline \multicolumn{7}{|l|}{ Origin } \\
\hline Ribeirão Preto & $\begin{array}{c}44 \\
(97.8)\end{array}$ & $\begin{array}{c}47 \\
(97.9)\end{array}$ & $\begin{array}{c}11 \\
(22.0)\end{array}$ & & & \\
\hline Ribeirão Preto region & $\begin{array}{c}01 \\
(2.2)\end{array}$ & $\begin{array}{c}01 \\
(2.1)\end{array}$ & $\begin{array}{c}29 \\
(58.0)\end{array}$ & & & \\
\hline Other cities in the state of São Paulo & & & $\begin{array}{c}07 \\
(14.0)\end{array}$ & & & \\
\hline Cities in other states & & & $\begin{array}{c}03 \\
(6.0)\end{array}$ & & & \\
\hline \multicolumn{7}{|l|}{ Marital status } \\
\hline Single (a) & $\begin{array}{c}04 \\
(8.9)\end{array}$ & $\begin{array}{c}04 \\
(08.3)\end{array}$ & $\begin{array}{c}03 \\
(6.0)\end{array}$ & & & \\
\hline Married/Stable relationship & $\begin{array}{c}23 \\
(51.1)\end{array}$ & $\begin{array}{c}25 \\
(52.1)\end{array}$ & $\begin{array}{c}37 \\
(74.0)\end{array}$ & & & \\
\hline Separated/Divorced & $\begin{array}{c}06 \\
(13.3)\end{array}$ & $\begin{array}{c}06 \\
(12.5)\end{array}$ & $\begin{array}{c}05 \\
(10.0)\end{array}$ & & & \\
\hline Widowed & $\begin{array}{c}12 \\
(26.7)\end{array}$ & $\begin{array}{c}13 \\
(27.1)\end{array}$ & $\begin{array}{c}05 \\
(10.0)\end{array}$ & & & \\
\hline Schooling (number of years) & $\begin{array}{c}4.1 \\
(3.5)\end{array}$ & $\begin{array}{c}6.4 \\
(4.4)\end{array}$ & $\begin{array}{c}4.8 \\
(3.6)\end{array}$ & $\begin{array}{c}04 \\
(0-12)\end{array}$ & $\begin{array}{c}05 \\
(0-17)\end{array}$ & $\begin{array}{c}04 \\
(0-15)\end{array}$ \\
\hline \multicolumn{7}{|l|}{ Occupation } \\
\hline Working & $\begin{array}{c}06 \\
(13.3)\end{array}$ & $\begin{array}{c}22 \\
(45.8)\end{array}$ & $\begin{array}{c}08 \\
(16.0)\end{array}$ & & & \\
\hline Retired with a paid job & $\begin{array}{c}04 \\
(8.9)\end{array}$ & $\begin{array}{c}00 \\
(00.0)\end{array}$ & $\begin{array}{c}00 \\
(0.0)\end{array}$ & & & \\
\hline Retired/Pensioner & $\begin{array}{c}17 \\
(37.8)\end{array}$ & $\begin{array}{c}15 \\
(31.3)\end{array}$ & $\begin{array}{c}32 \\
(64.0)\end{array}$ & & & \\
\hline Homemaker, no paid job & $\begin{array}{c}17 \\
(37.8)\end{array}$ & $\begin{array}{c}10 \\
(20.8)\end{array}$ & $\begin{array}{c}06 \\
(12.0)\end{array}$ & & & \\
\hline Unemployed/on sick leave & $\begin{array}{c}01 \\
(2.2)\end{array}$ & $\begin{array}{c}01 \\
(2.1) \\
\end{array}$ & $\begin{array}{c}04 \\
(8.0)\end{array}$ & & & \\
\hline Mean family income & $\begin{array}{l}1,622.4 \\
(977.8)\end{array}$ & $\begin{array}{c}2,176.2 \\
(1,454.4)\end{array}$ & $\begin{array}{c}1.884,3 \\
(1,796.9)\end{array}$ & & & \\
\hline Body mass index $\left(\mathrm{Kg} / \mathrm{m}^{2}\right)$ & $\begin{array}{l}31.2 \\
(5.7)\end{array}$ & $\begin{array}{l}31.9 \\
(5.5)\end{array}$ & $\begin{array}{l}32.3 \\
(5.2)\end{array}$ & $\begin{array}{c}30.4 \\
(22.65-47.3)\end{array}$ & $\begin{array}{c}31.1 \\
(20.21-47.2)\end{array}$ & $\begin{array}{c}32.4 \\
(22.6-46.4)\end{array}$ \\
\hline Systolic blood pressure (mmhg) & $\begin{array}{l}137.2 \\
(19.8)\end{array}$ & $\begin{array}{c}134 \\
(19.9)\end{array}$ & $\begin{array}{c}137.72 \\
(20.9)\end{array}$ & $\begin{array}{c}140 \\
(100-180)\end{array}$ & $\begin{array}{c}130 \\
(100-180)\end{array}$ & $\begin{array}{c}134.5 \\
(87-187)\end{array}$ \\
\hline Diastolic blood pressure (mmhg) & $\begin{array}{c}84.5 \\
(12.5)\end{array}$ & $\begin{array}{l}79.91 \\
(13.0)\end{array}$ & $\begin{array}{c}74.9 \\
(12.3)\end{array}$ & $\begin{array}{c}80 \\
(60-110)\end{array}$ & $\begin{array}{c}80 \\
(60-120)\end{array}$ & $\begin{array}{c}73 \\
(46-105)\end{array}$ \\
\hline Duration of diagnosis (years) & $\begin{array}{c}8.8 \\
(6.8)\end{array}$ & $\begin{array}{l}12.1 \\
(8.8)\end{array}$ & $\begin{array}{l}15.1 \\
(7.3)\end{array}$ & $\begin{array}{c}07 \\
(1-30)\end{array}$ & $\begin{array}{c}10 \\
(1-36)\end{array}$ & $\begin{array}{c}15 \\
(2-30)\end{array}$ \\
\hline HbA1c (\%) & $\begin{array}{c}6.75 \\
(1.27)\end{array}$ & $\begin{array}{l}6.64 \\
(1.2)\end{array}$ & $\begin{array}{l}9.73 \\
(2.0)\end{array}$ & & & \\
\hline
\end{tabular}

a In the PHC unit: Number of individuals in the sample with $\mathrm{BMI}=42$, and with Systolic blood pressure and Diastolic blood pressure $=43$ and $\mathrm{HbA} 1 \mathrm{c}=17$;

${ }^{b}$ In the SHC unit: Number of individuals in the sample with BMI = 42 and $\mathrm{HbA} 1 \mathrm{C}=29$;

c In the THC unit: Number of individuals in the sample with $\mathrm{HbA} 1 \mathrm{c}=48$. 
Table 2. Self-care activities presented by the sample concerning General Diet, Physical Activity, and Blood Glucose Monitoring domains from the SDSCA, Ribeirão Preto, SP, Brazil 2017.

\begin{tabular}{|c|c|c|c|c|c|c|c|}
\hline \multirow{2}{*}{ SDSCA domains } & \multicolumn{3}{|c|}{ Mean (SD) } & \multicolumn{3}{|c|}{ Median (minimum - maximum) } & \multirow{2}{*}{$p$-value } \\
\hline & PHC & SHC & THC & PHC & SHC & THC & \\
\hline General diet ( 2 items) & $4.11(2.41)$ & $3.80(2.30)$ & $4.15(2.44)$ & $3.50(0-7)$ & $3.50(0-7)$ & $3.50(0-7)$ & 0.33 \\
\hline Glucose Monitoring (2 items) & $1.54(2.59)$ & $2.40(2.90)$ & $3.93(2.70)$ & $0.00(0-7)$ & $1.00(0-7)$ & $4.00(0-7)$ & 0.00 \\
\hline
\end{tabular}

Statistical significance $p<0.05$ concerning the Kruskal-Wallis test.

Table 3. Self-care activities presented by the sample in the domains Specific Diet, Foot Care, and Medication addressed in the SDSCA, Ribeirão Preto, SP, Brazil 2017.

\begin{tabular}{|c|c|c|c|c|c|c|c|}
\hline SDSCA items & \multicolumn{3}{|c|}{ Mean (Standard -Deviation) } & \multicolumn{3}{|c|}{ Median (minimum - maximum) } & $p$-value \\
\hline 2 - Ingestion of fat-laden foods & $\begin{array}{c}3.40 \\
(2.89)\end{array}$ & $\begin{array}{c}3.29 \\
(2.53)\end{array}$ & $\begin{array}{c}2.52 \\
(2.72)\end{array}$ & $\begin{array}{l}3.00 \\
(0-7)\end{array}$ & $\begin{array}{l}4.00 \\
(0-7)\end{array}$ & $\begin{array}{l}1.00 \\
(0-7)\end{array}$ & $>0.05$ \\
\hline 3 - Ingestion of sweets & $\begin{array}{c}5.93 \\
(1.86)\end{array}$ & $\begin{array}{c}5.68 \\
(1.83)\end{array}$ & $\begin{array}{c}6.20 \\
(1.50)\end{array}$ & $\begin{array}{l}7.00 \\
(0-7)\end{array}$ & $\begin{array}{l}6.00 \\
(0-7)\end{array}$ & $\begin{array}{c}7.00 \\
(0-7)\end{array}$ & $>0.05$ \\
\hline 4 - Inspect feet & $\begin{array}{c}3.06 \\
(3.35)\end{array}$ & $\begin{array}{c}4.25 \\
(3.33)\end{array}$ & $\begin{array}{c}4.16 \\
(3.36)\end{array}$ & $\begin{array}{l}1.00 \\
(0-7)\end{array}$ & $\begin{array}{l}7.00 \\
(0-7)\end{array}$ & $\begin{array}{l}7.00 \\
(0-7)\end{array}$ & $>0.05$ \\
\hline 5 - Inspect inside of shoes & $\begin{array}{c}4.06 \\
(3.47)\end{array}$ & $\begin{array}{c}2.77 \\
(3.29)\end{array}$ & $\begin{array}{c}4.56 \\
(3.26)\end{array}$ & $\begin{array}{l}7.00 \\
(0-7)\end{array}$ & $\begin{array}{l}0.00 \\
(0-7)\end{array}$ & $\begin{array}{l}7.00 \\
(0-7)\end{array}$ & 0.01 \\
\hline 7 - Take insulin injections as recommended & $\begin{array}{c}7.00 \\
(0.00)\end{array}$ & $\begin{array}{c}6.41 \\
(1.97)\end{array}$ & $\begin{array}{c}7.00 \\
(0.00)\end{array}$ & $\begin{array}{l}7.00 \\
(7-7)\end{array}$ & $\begin{array}{l}7.00 \\
(0-7)\end{array}$ & $\begin{array}{l}7.00 \\
(7-7)\end{array}$ & 0.048 \\
\hline 8 - Take the prescribed number of DM pills & $\begin{array}{c}6.80 \\
(1.08)\end{array}$ & $\begin{array}{c}6.60 \\
(1.49)\end{array}$ & $\begin{array}{c}6.78 \\
(1.12)\end{array}$ & $\begin{array}{l}7.00 \\
(0-7)\end{array}$ & $\begin{array}{l}7.00 \\
(0-7)\end{array}$ & $\begin{array}{l}7.00 \\
(0-7)\end{array}$ & $>0.05$ \\
\hline
\end{tabular}

Statistical significance $p<0.05$ in the Kruskal-Wallis test.

a In PHC unit: Item $7 \mathrm{n}=05$ and item $08 \mathrm{n}=42$;

${ }^{b}$ In SHC unit: Items 2 and $4 \mathrm{n}=47$, item $4 \mathrm{n}=24$ and item $8 \mathrm{n}=38$;

c In UATS: Item $7 \mathrm{n}=44$ and item $8 \mathrm{n}=41$.

Table 4. Adherence to medication presented by the sample of three health units, Ribeirão Preto, SP, Brazil 2017.

\begin{tabular}{|c|c|c|c|c|c|c|c|c|c|}
\hline \multirow{2}{*}{ Variables } & \multicolumn{6}{|c|}{ Mean (standard-deviation) } & \multicolumn{3}{|c|}{ Median (minimum - maximum) } \\
\hline & $n$ & PHC & $\mathrm{n}$ & SHC & $n$ & THC & PHC & SHC & THC \\
\hline Adherence to insulin & 08 & $\begin{array}{c}5.60 \\
(0.33)\end{array}$ & 24 & $\begin{array}{c}5.48 \\
(0.48)\end{array}$ & 44 & $\begin{array}{c}5.68 \\
(0.47)\end{array}$ & $\begin{array}{c}5.64 \\
(5.00-6.00)\end{array}$ & $\begin{array}{c}5.57 \\
(4.29-6.00)\end{array}$ & $\begin{array}{c}5.86 \\
(3.71-6.00)\end{array}$ \\
\hline $\begin{array}{l}\text { Adherence to oral } \\
\text { antidiabetics }\end{array}$ & 42 & $\begin{array}{c}5.61 \\
(0.38)\end{array}$ & 37 & $\begin{array}{c}5.59 \\
(0.54)\end{array}$ & 40 & $\begin{array}{c}5.66 \\
(0.67)\end{array}$ & $\begin{array}{c}5.71 \\
(4.43-6.00)\end{array}$ & $\begin{array}{c}5.86 \\
(3.43-6.00)\end{array}$ & $\begin{array}{c}5.86 \\
(2.43-6.00)\end{array}$ \\
\hline
\end{tabular}

The Inspect inside shoes for foreign objects from the Foot Care domain presented differences in the mean frequencies of the units under study $(p<0.05)$, with a higher score in the THC unit, followed by the PHC and SHC units (Table 3).
In regard to specific adherence to medication (insulin and oral antidiabetic agents), the means found indicated good adherence behavior, that is, close to a mean score 6.0 for all the units (Table 4). 


\section{DISCUSSION}

The sociodemographic characteristics of the sample portray the profile of the population cared for by the SUS in the units included in this study, that is, low education and low income. There is also a greater frequency of female individuals aged approximately 60 years old in the three units, which is similar to data reported in other descriptive studies conducted in Brazil ${ }^{11,16,17,18}$.

The analysis of clinical data shows that the mean BMI found for all the units indicates obesity. One Brazilian cross-sectional study, the objective of which was to analyze treatment adherence in a sample of 417 people with DM2, aged 62.5 old on average $(S D=11.7)$, reports a mean BMl equal to $29.3(S D=5.3) \mathrm{Kg} /$ $\mathrm{m}^{2}$ and the analysis of frequency revealed that $299(79.1 \%)$ individuals presented an altered result ${ }^{12}$. Another Brazilian study conducted with 60 people with DM2, which investigated adherence to medication, reports that four $(6.7 \%)$ people presented BMI within normal parameters; 20 (33.3\%) were overweight; and $36(60 \%)$ were obese. ${ }^{18}$ In this context, actions to promote weight control should be implemented at all levels of health care because it is a risk factor for cardiovascular complications, which can affect glycemic control. 4,19,20

A national study that described the annual progression of the prevalence of excessive weight and obesity in the adult population of capitals in the 26 Brazilian states and the Federal District between 2006 and 2012 shows that excessive weight in the adult population increased from $43.2 \%$ in 2006 to $51 \%$ in 2012 , while obesity increased from $11.6 \%$ to $17.4 \%$ in the same period. ${ }^{21}$

In regard to the laboratory exams, the highest $\mathrm{HbA} 1 \mathrm{c}$, i.e., above the parameters recommended to control the disease, were found in the $\mathrm{THC}$ unit, while the $\mathrm{HbA} 1 \mathrm{c}$ presented by the $\mathrm{PHC}$ and $\mathrm{SHC}$ units were within normal parameters. The analysis of laboratory exams can be used to assess adherence to both medication and non-medication treatments, as both influence glycemic control. ${ }^{4}$

The duration of the diagnosis, associated with poor management, may be related to chronic complications from DM. The average time of the disease, except for the $\mathrm{PHC}$ unit, is longer than 10 years, and glycemic control assessed through $\mathrm{HbA1c}$ is above the ideal in the THC unit. ${ }^{4}$

Similar behaviors concerning adherence to self-care are found among the groups for the items: Ingestion of five or more portions of fruits and/or vegetables, Ingestion of fat-laden foods, Ingestion of sweets, Inspect feet, Dry between toes, and Take the prescribed number of pills.

Self-care activities that did not differ between the three levels of health care should be carefully analyzed, especially due to low adherence in regard to these activities, except for "ingestion of sweets", "dry the space between toes" and "take the prescribed number of pills", adherence regarding these activities was considered good. Note that assessing adherence using a self-report instrument may lead to bias, as people may check the answer they deem to be the most appropriate, rather than the most accurate one.
In regard to the items of the Specific Diet domain, the means concerning the ingestion of five or more portions of fruits and/ or vegetables in the last seven days were less than five in the three health care units. The minimum amount recommended for the ingestion of fruits and vegetables is five portions daily. ${ }^{19}$

The item concerning eating fat-laden foods also obtained low means in the three units, indicating a high frequency of foods like red meat, whole milk and its derivatives in the last seven days. Similar results were reported by a study conducted in Greece addressing a sample of 117 people with DM2, who presented sociodemographic characteristics similar to those reported in this study. ${ }^{22}$

A cross-sectional study conducted in $13 \mathrm{PHC}$ units in the city of Maceió, CE, Brazil addressing a sample of 225 individuals with high blood pressure and/or DM reports that socioeconomic situation is an important factor in accessing a healthy diet in terms of quantity and quality. ${ }^{23}$ Note that the samples from all three levels of care presented low educational levels and low family income, factors that may have contributed to greater consumption of fat-laden foods and less than the recommended amount of fruits.

The document published by the Ministry of Health reports a decrease in the consumption of fat-laden foods when individuals have more than 12 years of education. ${ }^{19}$ Inadequate diets may be related to low educational level, a condition found in this study sample (means below 6.6 years of education) and similar to that reported by Brazilian studies. ${ }^{6,7}$

In regard to the item assessing the ingestion of sweets, the average scores obtained by the $\mathrm{PHC}$ and $\mathrm{SHC}$ unit were similar, indicating less tendency to consume sweets over the course of a week. The THC unit obtained a slightly higher score.

Self-care behaviors analyzed by domain show a difference between the groups $(p<0.05)$ for the practice of physical activity and glucose monitoring. Self-care activities related to physical activities obtained higher scores in the THC unit and lower scores in the SHC unit. The practice of $\mathbf{3 0}$ minutes of physical activity, five days a week, is recommended for glycemic control. ${ }^{4}$ This mean was not found in the units, indicating that the practice of physical activity among the study's participants is less than what is recommended. Information that corroborate these results is reported in other studies. ${ }^{8,10}$

In regard to the Blood Glucose Monitoring domain, the $\mathrm{PHC}$ and SHC units obtained means less than those obtained by the THC unit. These means may be explained by the fact that the use of insulin is less frequent in the two units when compared to the THC unit. One Indian study reports findings similar to those found in this study because it was conducted in a THC unit where $76.6 \%$ of the participants monitored their blood glucose daily. ${ }^{24}$

The item Inspect shoes for foreign objects, which is from the Foot Care domain, presented a difference; that is, a greater frequency was found in the THC unit, probably due to education regarding diabetes mellitus that the unit implements and due to the contact the unit maintains with those who have ulcers. ${ }^{10}$ Habits regarding foot care are important actions to prevent complications,,$^{21,25}$ thus the item Dry toes after washing them, 
though it does not present an important difference, was the item in the Inspect Feet domain with the highest mean, a result also reported in another study. ${ }^{8}$ Therefore, the participants show they have the habit of taking care of their feet, but education regarding specific care needs to be continually reinforced.

It is believed that the difference found in the item Take insulin injections as recommended may be attributed to a shorter duration of diagnosis in the PHC unit, or even due to better glycemic control. The protocol of the Ministry of Health for DM recommends the initial treatment for the disease to include a healthy diet and the practice of exercise, and if no improvement is observed after three months from the point when a change of habits was implemented, oral antidiabetic agents should be initiated as monotherapy. Lack of glycemic control requires oral antidiabetic agents, and in situations where there is poor glycemic control, insulin is indicated. ${ }^{4,21}$

The participants from the THC unit obtained high scores for medication adherence; however, the mean $\mathrm{HbA1c}$ was $9.73 \%$ $(S D=2.05)$. These participants also obtained low scores in the items Ingestion of five or more portions of fruits and/or vegetables, Ingestion of fat-laden foods, and in the Physical Activity domain, which reinforces the importance of non-medication therapy.

A Brazilian cross-sectional study that used the MTA, a Food Frequency Questionnaire, and the International Physical Activity Questionnaire (the short IPAQ), does not report association between $\mathrm{HbA} 1 \mathrm{c}$ and medication adherence $(p=0.80)$, diet $(p=0.685)$, or physical activity $(p=0.124)$. In this last study, however, $98.3 \%$ did not adhere to diet plan, $41.9 \%$, did not adhere to physical activity, and $15.8 \%$ did not adhere to their medication, and $\mathrm{HbA} 1 \mathrm{c}$ were altered in $75.1 \%$ of the participants. ${ }^{11}$

The same was observed in a cross-sectional study with 218 people undergoing outpatient treatment, which also used the SDSCA and aimed to assess self-care activities related to DM and verify associations with sociodemographic and clinical data. It reports good adherence to medication with a mean of approximately six days/week for the use of medications and worse adherence in items concerning physical activity, with means close to two days/week, while the mean result of $\mathrm{HbA1c}$ was $9.5(\mathrm{SD}=2.0) \%{ }^{8}$

A cross-sectional study conducted in India, including 290 people with DM2 in a tertiary hospital, used the English version of SDSCA and reports that $43.4 \%$ performed physical activities daily, while $17.6 \%$ exercised daily. In regard to medication, $60.5 \%$ use oral antidiabetic agents daily and $66.9 \%$ received insulin shots daily. ${ }^{24}$

The results found in this study and reported by both Brazilian and international studies reinforce the need for patients to adhere to the three pillars of DM treatment, i.e., healthy diet, the practice of exercises, and medication, to achieve good glycemic control. ${ }^{8,11,24}$ An individual with DM may adhere to one self-care activity but not to others, as reported in the aforementioned studies, however, the literature presents DM treatment as a tripod composed of medication, exercise and healthy diet, on which success depends.
The assessment of the medication adherence variable shows that the results indicate there are individuals in all three levels of health care with behavior that reflects medication adherence, as other Brazilian studies show. , $^{810}$ One study validating the MTA oral antidiabetic agents and MTA insulin, which was developed with 90 individuals with DM2, reports a mean for adherence-to-insulin of $5.60(S D=0.45)$ and 5.60 for the use of oral antidiabetic agents $(S D=0.45) .{ }^{15}$ The study by Arrelias et al. $(2015)^{11}$, which also used MTA in the version in which adherence to both insulin and oral antidiabetic agents is assessed, reports high scores of medication adherence: $84.2 \%$ of adherence and $15.8 \%$ of non-adherence. The study conducted by Stilli et al. $(2015)^{18}$, in turn, which used the Brief Medication Questionnaire that classifies people as adherent, probably adherent, probably poorly adherent, and poorly adherent, in a sample of 60 people, reports that $15(25.0 \%)$ were adherent, $13(21.7 \%)$ were probably adherent, $18(30 \%)$ were probably poorly adherent, and 14 (23.3) were poorly adherent.

\section{CONCLUSION}

The sample from the three units presented similar results concerning high ingestion of fat-laden foods, low frequency of physical activity, and poor glycemic monitoring, which are essential to properly controlling the disease; that is, the participants obtained low scores for the instrument used to assess self-care activities, while the self-care activities that presented the highest scores were Ingestion of sweets, Dry between toes, and Medication; that is, greater adherence was found in these activities.

The THC unit presented some activities that obtained mean scores higher than those obtained in other activities, such as foot care and blood glucose monitoring, probably due to the need for insulin caused by poor glycemic control, evidenced by the greater percentage of $\mathrm{HbA1c}$. The main differences found between the three units may be related to the time since diagnosis and type of treatment. Even though glycemic monitoring is slightly better in the THC unit, all three units presented poor adherence to this item, probably because this study's participants have DM2 rather that type 1. Socioeconomic conditions may also hinder access to information and other resources that are essential for self-care.

The study also allowed reflection on the importance of being aware of the individuality of each participant in order to direct the care plan to his/her needs and also the need for further studies to identify motivational factors and barriers to the implementation of self-care activities.

In the complex sphere of self-care management, having knowledge of the therapeutic behavior of people with DM2 allows one to monitor treatment progression in order to implement new health care strategies whenever necessary.

Education at all health care levels is very important to qualifying and/or motivating adherence, generating autonomy and favoring improved glycemic control and reducing complications.

The evaluation of people in their self-care skills and adherence behavior may support the evaluation of the care plan and the measurement of the intended results. 
The main limitation of this study is the fact that the participants had to recall the self-care activities they had implemented in the last week.

\section{ACKNOWLEDGEMENTS}

To the National Council for Science and Technological Development (CNPq; Scientific Initiation Scholarship). To the São Paulo Research Foundation (FAPESP; Research Support - Regular, process 2011/08937-6).

\section{REFERENCES}

1. Ministério da Saúde (BR). Pesquisa Nacional de Saúde 2013: Percepção do estado de saúde, estilos de vida e doenças crônicas; Grandes Regiões e Unidades da Federação. [Internet]. Rio de Janeiro; 2014 [cited 2016 Nov 5]. 105 p. Available from: ftp://ftp.ibge.gov.br/ PNS/2013/pns2013.pdf

2. International Diabetes Federation. Diabetes Atlas. [Internet]. 7th ed. 2015 [cited 2016 Nov 5]. Available from: http://www.diabetesatlas.org/

3. Michels MJ, Coral MHC, Sakae TM, Damas TB, Furlanetto LM. Questionário de Atividades de Autocuidado com o Diabetes: tradução, adaptação e avaliação das propriedades psicométricas. Arq Bras Endocrinol Metab [internet]. 2010 Oct; [cited 2016 Nov 5]; 54(7):64451. Available from: http://www.scielo.br/scielo.php?script=sci_ar ttext\&pid=S0004-27302010000700009 DOI: 10.1590/S000427302010000700009

4. Sociedade Brasileira de Diabetes - SBD. Diretrizes da Sociedade Brasileira de Diabetes. 2016; [cited 2016 Nov 5]. Available from: http:// bibliofarma.com/diretrizes-sbd-2015-2016/

5. Delamater AM. Improving patient adherence. Clin Diabetes [Internet]. 2006 Apr; [cited 2015 Apr 15]; 24(2):71-7. Available from: https://doi. org/10.2337/diaclin.24.2.71

6. Rezende Neta DS, Silva ARV, Silva GRF. Adherence to foot self-care in diabetes mellitus patients. Rev Bras Enferm [Internet]. $2015 \mathrm{Jan} /$ Feb; [cited 2016 Nov 10]; 68(1):111-6. Available from: http://www. scielo.br/scielo.php?pid=S0034-71672015000100111\&script=sci_ arttext\&tlng=en DOI: 10.1590/0034-7167.2015680115p

7. Faria HTG, Santos MA, Arrelias CCA, Rodrigues FFL, Gonela JT, Teixeira CRS, et al. Adherence to diabetes mellitus treatments in Family Health Strategy Units. Rev Esc Enferm USP [Internet]. 2014 Apr; [cited 2016 Nov 10]; 48(2):257-63. Available from: http://www.scielo.br/ scielo.php?script=sci_arttext\&pid=S0080-62342014000200257 DOI: 10.1590/S0080-623420140000200009

8. Coelho ACM, Villas Boas LCG, Gomides DS, Foss-Freitas MC, Pace AE. Self-care activities and their relationship to metabolic and clinical control of people with diabetes mellitus. Texto Contexto Enferm [Internet]. $2015 \mathrm{Jul} / \mathrm{Sep}$; [cited 2016 Nov 10]; 24(3):697705. Available from: http://www.scielo.br/scielo.php?script=sci_ar ttext\&pid=S0104-07072015000300697 DOI: 10.1590/010407072015000660014

9. Villas Boas LCG, Foss-Freitas MC, Pace AE. Adherence of people with type 2 diabetes mellitus to drug treatment. Rev Bras Enferm [Internet]. 2014 mar/abr; [cited 2016 Out 10]; 67(2): 268-73. Available from: http:// www.scielo.br/pdf/reben/v67n2/0034-7167-reben-67-02-0268.pdf

10. Gomides DS, Villas Boas LCG, Coelho ACM, Pace AE. Self-care of people with diabetes mellitus who have lower limb complications. Acta Paul Enferm [Internet]. 2013; [cited 2016 Nov 10]; 26(3):28993. Available from: http://www.scielo.br/scielo.php?pid=S010321002013000300014\&script=sci_arttext\&tIng=en DOI: 10.1590/ S0103-21002013000300014

11. Arrelias CCA, Faria HTG, Teixeira CRS, Santos MA, Zanetti ML. Adherence to diabetes mellitus treatment and sociodemographic, clinical and metabolic control variables. Acta Paul Enferm [Internet]. 2015
Jul/Aug; [cited 2016 Nov 10]; 28(4):315-22. Available from: http://www. scielo.br/scielo.php?pid=S0103-21002015000400005\&script=sci_ arttext\&tIng=en DOI: 10.1590/1982-0194201500054

12. Toobert DJ, Hampson SE, Glasgow RE. The Summary of Diabetes SelfCare Activities Measure: Results from 7 studies and a revised scale. Diabetes Care [Internet]. 2000 Jul; [cited 2016 Nov 10]; 23(7):943-50. Available from: https://www.ncbi.nlm.nih.gov/pubmed/?term=The+Su mmary+of+Diabetes+Self- Care+Activities+Measure\%3A+Results+fr om+7+studies+and+a+revised+scale

13. Delgado $A B$, Lima ML. Contributo para a validação concorrente de uma medida de adesão aos tratamentos. Psic Saúde Doenças [Internet]. 2001 Nov; [cited 2016 Nov 10]; 2(2):81-100. Available from: http://www.scielo.mec.pt/scielo.php?script=sci_arttext\&pid =S1645-00862001000200006

14. Morisky DE, Green LW, Levine DM. Concurrent and predictive validity of a self-reported measure of medication adherence. Med Care [Internet]. 1986 Jan; [cited 2016 Nov 10];24(1):67-74. Available from: https://www. ncbi.nlm.nih.gov/pubmed/3945130

15. Villas Boas LCG, Lima MLSAP, Pace AE. Adherence to treatment for diabetes mellitus: validation of instruments for oral antidiabetics and insulin. Rev Latino Am Enferm [Internet]. 2014 Jan/Feb; [cited 2016 Nov 10]; 22(1):11-8. Available from: http://www.scielo.br/ scielo.php?script=sci_arttext\&pid=S0104-11692014000100011DOI: 10.1590/0104-1169.3155.2386

16. Zanetti ML, Arrelias CCA, Franco RC, Santos MA, Rodrigues FFL, Faria HTG. Adesão às recomendações nutricionais e variáveis sociodemográficas em pacientes com diabetes mellitus. Rev Esc Enferm USP [Internet]. 2015 Jul/Aug; [cited 2016 Nov 10]; 49(4):619-25. Available from: www.scielo.br/scielo.php?script=sci_ arttext\&pid=S0080-62342015000400619\&Ing=en\&nrm=iso

17. Augusto MC, Nitsche MJ, Parada CMGL, Zanetti ML, Carvalhaes MA Evaluation of the Capillary Blood Glucose Self-monitoring Program. Rev Latino Am Enferm [Internet]. 2014 Oct; [cited 2016 Nov 10];22(5):801-9. Available from: https://www.ncbi.nlm.nih.gov/pubmed/25493676

18. Istilli PT, Pereira MCA, Teixeira CRS, Zanetti ML, Becker TAC, Marques JVP. Treatment adherence to oral glucose-lowering agents in people with diabetes: Using the Brief Medication Questionnaire. J Diabetes Nurs [internet]. 2015; [cited 2016 Nov 10]; 19(9):340-8. Available from http://www.diabetesonthenet.com/journal-content/view/treatmentadherence-to-oral-glucose-lowering-agents-in-people-with-diabetesusing-the-brief-medication-questionnaire

19. Ministério da Saúde (BR). VIGITEL: Vigilância de fatores de risco e proteção para doenças crônicas por inquérito telefônico. [Internet] Brasil: Ministério da Saúde, Agência Nacional de Saúde Suplementar. Brasília (DF): Ministério da Saúde;2015. [cited 2016 Nov 10]. Available from: http://bvsms.saude.gov.br/bvs/publicacoes/vigitel_brasil_2014. pdf

20. American Diabetes Association. Standards of Medical Care in Diabetes Diabetes Care [Internet]. 2015 Jan; [cited 2016 Nov 5]; 38(Supp 1):S20-S80. Available from: http://care.diabetesjournals.org/content/ suppl/2014/12/23/38.Supplement_1.DC1/January_Supplement_ Combined_Final.6-99.pdf

21. Malta DC, Andrade SC, Claro RM, Bernal RT, Monteiro CA. Trends in prevalence of overweight and obesity in adults in 26 Brazilian state capitals and the Federal District from 2006 to 2012. Rev Bras Epidemiol [Internet]. 2014; [cited 2017 Jul 23]; 17 Suppl 1:267-76. Available from: https://www.ncbi.nlm.nih.gov/pubmed/25054269 DOI: 10.1590/18094503201400050021

22. Chourdakis M, Kontogiannis V, Malachas K, Pliakas T, Kritis A. Selfcare behaviors of adults with type 2 diabetes mellitus in Greece. J Community Health [Internet]. 2014 Oct; [cited 2016 Nov 10]; 39(5):9729. Available from: https://www.ncbi.nlm.nih.gov/pubmed/24519180 DOI: 10.1007/s10900-014-9841-y

23. Vasconcelos SML, Torres NCP, Silva PMC, Santos TMP, Silva JVL, Omena CMB, et al. Insegurança Alimentar em Domicílios de Indivíduos Portadores de Hipertensão e/ou Diabetes. Int J Cardiovasc Sci 
[Internet]. 2015 Jan/Feb; [cited 2017 May 5]; 28(2):114-21. Available from: http://www.onlineijcs.org/sumario/28/pdf/v28n2a06.pdf

24. Rajasekharan D, Kulkarni V, Unnikrishnan B, Kumar N, Holla R, Thapar R. Self-Care Activities Among Patients with Diabetes Attending a Tertiary Care Hospital in Mangalore Karnataka, India. Ann Med Health Sci Res [Internet]. $2015 \mathrm{Jan} / \mathrm{Feb}$; [cited $2016 \mathrm{Nov}$ 10]; 5(1):59-64. Available from: https://www.ncbi.nlm.nih.gov/pubmed/25745579 DOI: 10.4103/21419248.149791
25. Bakker K, Apelqvist J, Lipsky BA, Van Netten JJ; International Working Group on the Diabetic Foot.. The 2015 International Working Group on the Diabetic Foot guidance documents on prevention and management of foot problems in diabetes: development of na evidence-based global consensus. Diabetes Metab Res Rev [Internet]. 2016 Jan; [cited 2017 Jul 23]; 32 Suppl 1:2-6. Available from: https://www.ncbi.nlm.nih.gov/ pubmed/26409930 DOI: 10.1002/dmrr.2694 